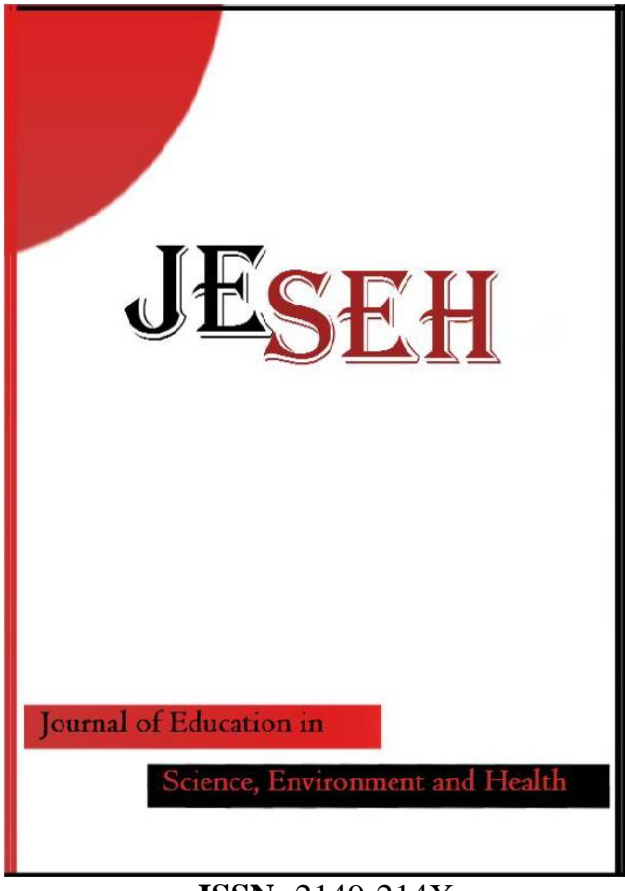

ISSN: $2149-214 \mathrm{X}$

\section{Journal of Education in Science, Environment and Health}

www.jeseh.net

Measuring Scientific Process Skills with Different Test Formats: A Research from the Perspective of Cognitive Styles

Sema Aydin Ceran', Salih Ates ${ }^{2}$

${ }^{1}$ Selcuk University

${ }^{2}$ Gazi University

To cite this article:

Aydin-Ceran, S. \& Ates, S. (2020). Measuring scientific process skills with different test formats: A research from the perspective of cognitive styles. Journal of Education in Science, Environment and Health (JESEH), 6(3), 220-230. DOI:10.21891/jeseh.703442

This article may be used for research, teaching, and private study purposes.

Any substantial or systematic reproduction, redistribution, reselling, loan, sub-licensing, systematic supply, or distribution in any form to anyone is expressly forbidden.

Authors alone are responsible for the contents of their articles. The journal owns the copyright of the articles.

The publisher shall not be liable for any loss, actions, claims, proceedings, demand, or costs or damages whatsoever or howsoever caused arising directly or indirectly in connection with or arising out of the use of the research material. 


\title{
Measuring Scientific Process Skills with Different Test Formats: A Research from the Perspective of Cognitive Styles
}

\author{
Sema Aydin Ceran, Salih Ates
}

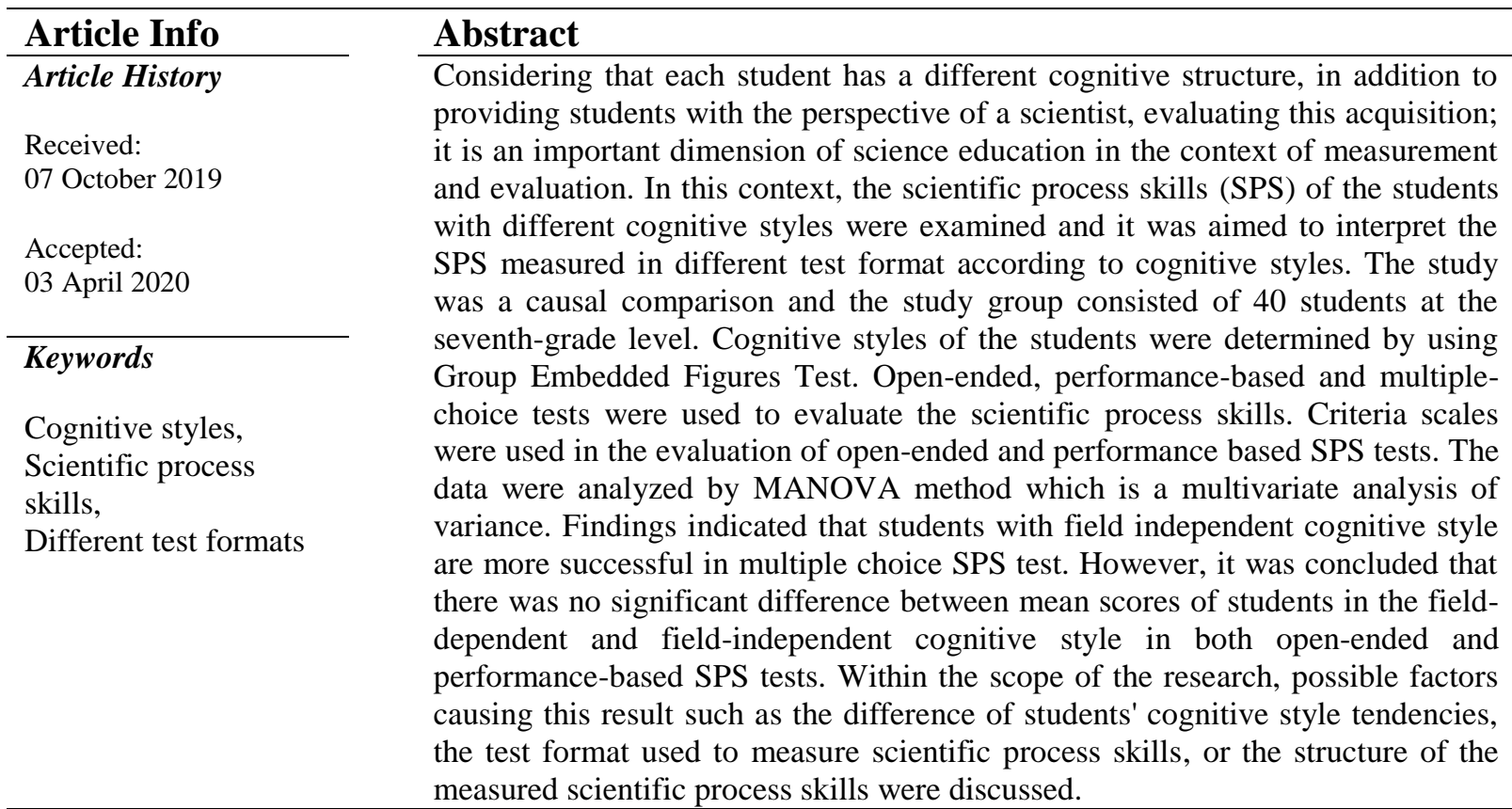

\section{Introduction}

Lowery (1997, p.112) expresses the relationship of children with science in National Science Teacher Association (NSTA) Pathways to the Science Standards guidebook as follows;

Every child is born a scientist. Children have the nonstop curiosity that prompts them continually to compare their internal world with the input of their senses and struggle to make sense of it all. It is the challenge of elementary science to keep that curiosity alive.

In elementary science, the development and evaluation of "scientific process skills" is an important factor in overcoming this difficulty and maintaining children's curiosity in learning science. However, researchers emphasize that scientific process skills reflect the behavior of scientists and the processes that scientists follow in accessing information (Meador, 2003; Padilla, 1990; Rezba, Sprague, McDonnough, and Matkins, 2007). When the national education curricula of the countries that are successful in the PISA study organized by Organization for Economic Co-Operation and Development (OECD) every three years are examined, it is noteworthy that the focus is on scientific process skills from pre-school to university period. As a matter of fact, the Programme for International Student Assessment (PISA) research emphasized what the student knows and can do with it (OECD, 2019). Parkinson (1988, p.8) stated that a scientific method is more important than remembering scientific facts in discussions about science processes. At this point, issues such as acquiring, developing and evaluating scientific process skills become an important dynamics of education systems.

\section{Scientific Process Skills and Importance}

When the perspectives of the researchers on the scientific process skills are examined in the literature, it is remarkable that they refer to the concepts of a tool/implementation (Harlen, 1999; Ostlund, 1992) in learning, producing and organizing information. Science-A Process Approach (SAPA) has been grouped scientific process skills as basic and integrated skills, which facilitate learning, acquire research ways and methods, enable 
students to be active, develop the sense of taking responsibility in their own learning and increase the permanence of learning in science (Tan and Temiz, 2003). Padilla (1990) stated that Basic Science Process Skills are classification, communication, measurement, inference and prediction. Scientific process skills should not be considered only as the ability to carry out the stages in solving a scientific problem (Ergin, Şahin Pekmez and Öngel-Erdal, 2005).

It is necessary to evaluate scientific process skills as a lifelong skill and an understanding development in understanding daily life and solving the problems encountered. Because an individual who acquires scientific process skills can solve a problem, he/she encounters in daily life by using scientific methods. For example, a farmer, who is engaged in animal husbandry, can make various experiments on nutrition, collect data, find information about animal breeding methods in the country and in the world and compare them with their own methods in order to obtain milk in the highest yield. As a matter of fact, the success of science today is proportional to the ability of the student to transform the science knowledge learned at school into a skill in daily life. When the PISA questions that OECD performs every three years are examined, it is remarkable that the questions address a problem encountered in daily life. In PISA research (in terms of science literacy), highlevel competencies point out the ability of the student to use the science knowledge in a wide range of contexts in a creative and autonomous way (OECD, 2019). Starting from the fact that scientific process skills have an important role in science education, countries especially include the development of process skills in science education programs.

\section{Measuring Scientific Process Skills}

Besides acquiring and developing scientific process skills, it is also important to measure these skills, evaluate their development and interpret them in a meaningful way. Based on this importance, various scales of scientific process skills have been developed abroad since the 1960s. When these scales are examined, it is noteworthy that most of them determine their scientific process skills with multiple choice tests (Aydogdu, Tatar, Y1ldız and Buldur, 2012; Burns, Okey and Wise, 1985; Dillashaw and Okey, 1980; Demirçalı, 2016; Feyzioğlu, Akyıldız, Demirdag and Altun, 2012; Molitor and Kenneth, 1976). In order to measure the skills of middle school and high school students to create and interpret line graphs, a test was developed by Mckenzie and Padilla in 1985 in a multiple-choice format with the original name The Test of Graphing in Science (TOGS). This test was later modified by Adam and Shrum in 1990 with open-ended standards and was prepared for use in individual evaluations rather than class evaluations (Ateş, 2001).

When the literature is examined, there are also studies that determine the scientific process skills based on performance. For example, Solano-Flores (2000) asked students to design an experiment by giving them various solutions and experimental materials, and to find out the factors influencing the creation of soap bubbles by experimenting. Ateş (2005) developed the "Ability Test for Determining and Controlling Variables", which has an open-ended format to determine the ability to identify and control variables. Temiz (2007) created a SPS question pool consisting of a total of six modules, three of which are multiple choice and three are open ended. Aktamis and Sahin Pekmez (2011), on the other hand, developed a measurement and evaluation tool with multiple types of questions to evaluate scientific process skills with different measurement and evaluation techniques. The test includes multiple choice, matching, gap filling, open-ended, and structured questions. Özkan (2015) designed the scientific process skills scale for 60-72 months old children in a structure that includes instructions such as "-there are buttons of different sizes here, -group these buttons and reassemble buttons and stones by other features". Based on this literature summary, we can say that the course of research aimed at measuring scientific process skills in the literature draws attention to the perception that has changed from past to present.

It is seen that there is a transition and change in the question types from multiple choice test format to open ended, performance based, structured etc. test formats. However, it is a remarkable issue that these studies are limited. From this point of view, when the literature is examined, the necessity of comparing scientific process skills with different types of questions arises. The scarcity of studies in this field in the literature suggests that the evaluation of scientific process skills with only one question type is a factor that should be discussed. In this study, this factor is one of the main objectives in measuring students' scientific process skills with different test formats. Another reason for the use of different types of question types is the individual differences that students have. In education, gender, physical characteristics, socio-cultural-economic-demographic characteristics of the student, etc. can be mentioned about many different individual characteristics that should be taken into account. Cognitive styles are just one of these individual differences. 


\section{Cognitive Styles as an Individual Difference}

Witkin, Moore, Goodenough and Cox (1977) expressed cognitive style as the preferred way/method in the process of retrieving, organizing, applying, remembering and storing it for use when necessary. Sternberg and Grigorenko (1997) emphasized that cognitive styles represent a bridge between cognition and personality, two different areas of psychological research. However, cognitive styles should not be perceived as a mental ability. Studies that point to the difference between cognitive styles and mental (intellectual) abilities (Messick, 1982; Witkin, 1977) argue that mental abilities are specific to verbal or numerical content or area, while cognitive styles intersect with both talent and personality areas. According to Messick (1982), the dimensions of intellectual talent mainly refer to the level of content and cognition. However, while mental ability requires What? how? what kind of information is processed by which process, which format and how well? questions, cognitive styles express cognition style and form (p.7-10). From this point of view, we can say that cognitive styles reflect a cognitive wording in the organization of knowledge and experience, not a mental ability. It is important to reflect the cognitive styles, which is a characteristic feature, to the educational process (Messick, 1982; Sternberg and Grigorenko, 1997). Witkin and Goodenough (1981) addressed individuals in two ways: field-dependent and field-independent in terms of their cognitive styles. This polar structure, also known as a psychological differentiation, refers to the extent to which a person's perceptual space is dependent on this perceptual space regardless of the organization (Sternberg and Grigorenko 1997).

In the field-dependent cognitive style, the overall organization of the total perceptual space dominates the individual's recognition of a pattern. On the contrary, in the field-independent cognitive style, the individual is more likely to see parts of the field separate from the organized space (Witkin, Oltman, Raskin and Karp, 1971, p.4). It is possible to see that field dependent and field independent students have the same level of cognitive capacity. However, their ability to use information and the process of using materials may differ (Sari, Altiparmak and Ates, 2013; Saracho, 1997). In addition, Riding and Rayner (2012) stated that the correlation between intelligence and cognitive style tests is very low, even close to zero.

Students with field independent cognitive style are more successful in remembering details, words and concepts, and writing what they hear. They like to work individually. They prefer teaching methods that discover and question. Field dependent students are successful in summarizing, remembering visualized concepts, prefer a social teaching environment because they like interpersonal interaction (Jonassen and Grabowski, 1993; Rasinski, 1984). This characteristic difference of individuals indicates that learning activities, teaching and assessment methods should also be different.

Because the way each student configures information in his mind and reflect this structure is different. According to Messick (1982), who has many studies leadings the field in cognitive styles; education should deal with not only information but also the way the student thinks. The goals and objectives in education should be expanded with the development of strategic thinking and flexibility in the use of multiple thinking methods. Based on the potential contributions of the reflection of cognitive styles of Samuel Messick into educational environments (1982, p.7-10), it can be said that the use of measurement tools suitable for every cognitive style in the assessment and evaluation dimension will make a decisive difference in the outcomes of education and training.

In this study, it was aimed to provide diversity of implementations by using measurement tools in different formats in the evaluation of scientific process skills. Thus, it was aimed to draw attention to the need to eliminate the drawbacks in measuring scientific process skills by uniform tests. In addition, the interaction of tests in different formats used in measuring scientific process skills with cognitive styles was observed. It is thought that this dimension of the research will fill the gap in the field.

\section{Method}

\section{Research Goal}

The aim of this research is to determine the scientific process skills of seventh grade students with different cognitive styles by measuring tools in different formats and interpret them according to field dependent/field independent cognitive styles. 


\section{Research Design}

This study was designed as a causal comparative study. Causal comparative method includes the comparison of samples which differ in critical variables but are comparable (Balci, 2005, p.264). Cohen, Manion and Morrison (2002) stated that in the causal comparison studies, there are at least two groups effected differently from the same situation. Briefly, in order to determine the possible causes and effects of the present situation, these groups are examined in terms of some variables. In this study, field dependent and field independent cognitive styles of the students were determined and the effect of these variables on the mean scores obtained from different measurement techniques used to determine scientific process skills was examined. However, causal comparison studies should not be confused with empirical research trying to establish a cause-effect relationship. As a matter of fact, in the case of causal comparison research, the situation investigated unlike the experimental researches arises independently from the manipulation of the researcher (Cohen, Manion and Morrison, 2002).

\section{Sample}

The population of the research is the seventh-grade students studying in Mamak locality of Ankara province. The sample of the study consists of seventh grade students studying in a public school in mamak locality. Since a comparison will be made according to the cognitive style differences of the students in the study group, firstly the cognitive style tendency of the students in the study group was determined. The Group Embedded Figure Test was applied to 80 students studying at seventh grade level in the school. As a result of the implementation, it was determined that 34 students were field dependent, 37 students were field independent, and nine students had field-intermediate cognitive style. Since it is desired to make a comparison between the scientific process skills of the field dependent and field independent students according to the SPS test formats, the students with the field-intermediate cognitive style were excluded from the scope of the research.

Two criteria that are taken as the basis for determining the study group are the gender factor and the previous semester's science course grades of students. The main rationale for the science course achievement points (school report) criterion is to ensure the equivalence of students (field dependent and field independent cognitive style) in terms of success before applying the SPS tests. In this context, 20 students from each cognitive style, whose science course achievement points were close, were selected. Care was taken to ensure that the selected students are equal in gender (for both cognitive styles). The t-test was conducted to examine the equivalence of students in the field-dependent and field-independent cognitive style in terms of the science course achievement points (school report), and there was no significant difference between the groups [t $(38)=2.59$, p> .05]. In summary, the study group of the study consists of 40 seventh grade students ( 20 female and 20 male) selected from different class of a public school in Ankara.

\section{Data Collection Tools}

Within the scope of the research, four different data collection tools were used.

\section{Group Embedded Figures Test}

Group Embedded Figures Test was used to identify field dependent/independent cognitive styles. This test was developed by Oltman, Raskin and Witkin (1971). It is still popular today and preferred by researchers to examine differences from cognitive styles (Karaçam and Ates, 2010; Mefoh, Nwoke, Chukwuorji and Chijioke, 2017; Saracho, 1997; Özarslan and Bilgin, 2016).

The test consists of three parts. In the first part, seven questions are easy and students are expected to practice. In the other two parts, there are nine questions with increasing difficulty. For these two parts, students are given five-minute periods. Students' cognitive tendencies are determined according to their answers to 18 questions in the last two sections. The questions in the first part are not included in the scoring because the students are intended to practice. The score can be graded between 0-18 and the students who are of the most correct in determining the simple shape within the complex shape are classified as field independent and the students with the least correct are classified as field dependent. In this study, the method formulated by Alamolhodaei (1996) was used to classify the cognitive styles of the students. 


\section{Scientific Process Skills (SPS) Multiple Choice and Open-ended Test}

In the research, "Scientific Process Skills Measurement Test" developed by Temiz (2007) was used to examine students' scientific process skills. The scope of the SPS Measurement Test; It consists of six modules consisting of determining variables, create hypotheses, changing and controlling variables, saving data (creating a data table), drawing graphics and interpreting graphics. Temiz (2007) designed the SPS Measurement Test as a pool of questions that can be used in scientific process skills researches and in-class activities and foresees users to take the appropriate number and quality of materials according to their needs and create their own tests. In this regard, within the scope of the research, the Scientific Process Skills Measurement Test question pool has the ability to determine variables and create hypotheses one open-ended and five multiple-choice, experimentdesign-ability one open-ended and two multiple-choice, seven multiple-choice from the ability to interpret data, save data and draw graphics two open-ended questions were chosen. In summary, the multiple choice SPS test consists of fourteen questions and the open-ended SPS test consists of four questions. For the validity and reliability analysis of the Multiple Choice SPS test, the pilot test was applied to 210 students. In the Multiple Choice SPS test, the student gets one point for the correct answer and zero point in all other possibilities. Accordingly, the maximum score a student can get from the test is 14 , and the minimum score is zero. In accordance with the data obtained from the pilot implementation, the Cronbach Alpha value, which is the internal consistency coefficient of the multiple choice SPS test, was found 0.78 . The average item difficulty of the test was calculated as 0.506 and the average item discrimination index as 0.41 . The implementation time of the test is 25 minutes. The questions in the open-ended part of the SPS Test were evaluated according to Temiz's (2007) analytical criteria scales. In this context, a student can get a maximum of 54 points from the test (with a maximum of 22 points from the first question, a maximum of seven points from the second question, a maximum of 15 points from the thirth question and a maximum of ten points from the fourth question). The response time of the test is 25 minutes. In order to test the reliability of the scoring made by the researcher in the evaluation of open-ended questions according to the analytical criteria scales, the answer sheets of ten students randomly selected from 40 students were scored by two separate raters other than the researcher. The first author took place as the third rater in the process. Whether there is a difference between the point averages given by the raters was tested by one-way analysis of variance and reliability between raters was determined. The findings show that there is no statistically significant difference between the scores assigned by the three raters $[F(2,327)=.000, p>0.05]$.

\section{Performance Based SPS Test}

The measurements that the student is asked to show her/his knowledge by creating an answer or by making a product are expressed as performance-based measurements (Century, 2002). In such measurements, a student needs to research, inquiry and use his/her prior knowledge to solve the given problem or to perform a task. In this case, measurement is also an element that increases learning (Bekiroglu-Ogan, 2008). Scientific process skills require a performance-based evaluation activity by nature. In this study, a semi-structured test was developed to measure students' scientific process skills based on performance. In the development of the performance test, Spector's (1992) cycle has been accepted, which includes the processes of defining the structure, designing the scale, pilot implementation, item analysis, validity and norming processes. In this context, the steps followed in the development of the performance based SPS test are presented respectively.

\section{Stage 1-Performance-based scientific process skills and subject selection}

Firstly, it is determined which scientific process skills the test will contain. In this context, the focus is on the skills in which the student can best demonstrate his cognitive, effective and psychomotor skills. In this framework, a daily life situation was chosen in which the student can demonstrate the skills of determining the problem, creating hypothesis, determining and controlling variables, designing experiments, collecting data, recording and interpreting data and drawing conclusions. In the subject selection, energy, which is a subject that the students have already learned, was preferred. As a matter of fact, Bozkurt and Olgun, (2005) stated that it is not correct to evaluate the scientific process skills in a subject that students do not know or have an idea about. In this framework, students were told a story about "a day of Beril and her mother, who is a civil engineer, on the construction site" and the visuals in the story (construction site, crane, construction, warning signs, hard hat, etc.) were reflected on the writing board. Students were given a problem situation from daily life within the scope of gravitational potential energy. The choice of a construction and crane close to the school was effective 
in choosing this daily life situation. Because it is thought that choosing an event that the student is familiar with from daily life will increase the student's interest to the problem situation in the affective sense.

\section{Stage 2-Content structure of the Performance Based SPS test in the context of skills}

In the performance based SPS test, the problem status and the materials to be used in the experiment were given to the students by the teacher. A semi-structured format was preferred in the creation of the test draft considering the grade level of the students. In this context, students were asked to design an experiment using the materials provided to explain their daily life status. The performance based SPS includes the skills presented in Figure 1.

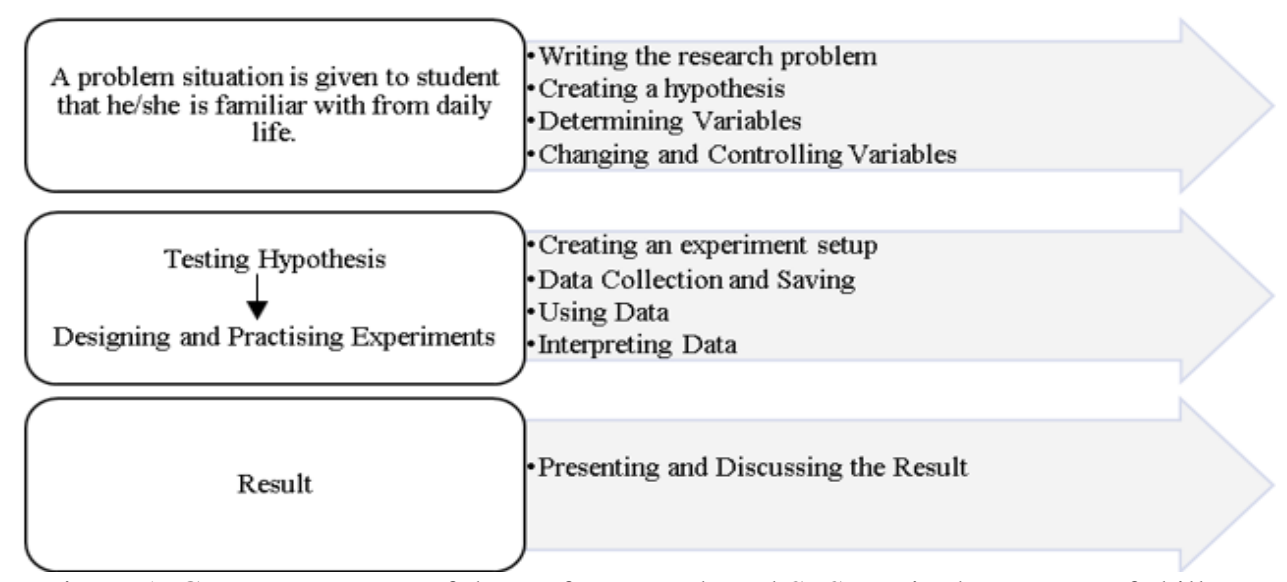

Figure 1. Content structure of the performance based SPS test in the context of skills

\section{Stage 3- Expert opinion}

The draft prepared was evaluated by three field experts in line with the criteria given in Table1.

Table 1.Criteria considered in the creation of a performance based SPS test

Criteria
The compliance of the given daily life context to the content/subject.
The Compliance of the given daily life context with the scientific process skills to be observed.
The Compliance of the performance task with the scientific process skills to be observed.
The Compliance of the given daily life context, questions and instruction to the age and grade level of the student.
The Compliance of the time given to the student to complete the performance based SPS test.
The Compliance of the instructions and questions asked in the performance task to reveal the knowledge and skills to be
measured (Wiggins, 1996).
The given daily life context, questions and instruction are clear and understandable.
The suitability of the Analytical Criteria Scale to the scientific process skills to be measured
The criteria in the Analytical Criteria Scale are clear and understandable.

In line with the opinions and suggestions of the field experts, the Performance Based SPS Test was given final mode before the pilot implementation.

\section{Stage 4-Pilot implementation}

Performance based SPS pilot test was applied to ten students. With the pilot implementation, students' response time of test, concepts and terms they could not understand, and sections that were not understood in the directive were determined. Arrangements were made in accordance with these determinations and the completion time of the test was determined as 30 minutes. In pilot practice, it was determined that students did not know some concepts about SPS. In addition, it has been observed that performing the performance task in a daily life context increases the students' interests and motivations. 


\section{Stage 5- Creating an analytical criterion scale}

In the research was based on a process-based assessment approach in terms of performance evaluation. For this reason, Analytical Criteria Scale was used for evaluation. According to Temiz (2007), the analytical criterion scale is the form of performance divided into different levels. Analytical criteria scale is created to give different grades to different dimensions of a study or product. When evaluating with the analytical criterion scale, it is necessary to focus on the process evaluation more than product evaluation. In this study, SPS scale development studies of Temiz (2007) and Aktamıs and Sahin Pekmez (2011) were utilized in establishing the criteria of the scale used in evaluating the performance based SPS test. In this context, a Performance Evaluation Analytical Criterion Scale was created in line with the Experimental Design Evaluation Analytical Criterion Scale, the Experimental Design Analytical Criterion Scale (Temiz, 2007) and the measured skills and expected behaviors (Aktamis and Sahin Pekmez, 2011). In addition, the data obtained from the pilot implementation were also used in the development of the analytical criterion scale.

\section{Analyzing of Data}

In the research, One Way MANOVA method was used to determine whether there is a difference in the scores obtained from different SPS tests formats according to cognitive styles (field dependent/ independent). MANOVA is a powerful and multivariate statistics used in experimental and scan study (Büyüköztürk, 2007; p: 138). Analyzes were presented in the Findings section.

\section{Findings}

In this section, firstly, the findings related to the assumptions of MANOVA and then the findings related to the analysis of the data obtained from the research with the method of MANOVA are given.

\section{Findings Related to Providing Assumptions of MANOVA}

Whether the scientific process skills measured by tests in different formats differ according to the cognitive styles that students have (field dependent/independent) were tested with MANOVA. Accordingly, statistical assumptions required for the analysis of MANOVA for one independent (cognitive style) and three dependents (multiple choice, open-ended and performance-based SPS) variables were tested. First, Box's M test was performed to examine the distribution of covariance matrices. The test results showed that MANOVA analysis can be performed and variance covariance matrices of dependent variables are evenly distributed (Box's M = $9,309 \mathrm{p}>.05)$. Thus, the assumption of equal distribution of covariance matrices, one of the basic assumptions of multiple variance analysis, was met. Levene's Test results for the homogeneity of variances are given in Table 2.

Table 2.Levene's test results for homogeneity of variances

\begin{tabular}{llll}
\hline Dependent Variable & $s d 1 / s d 2$ & $F$ & $P$ \\
\hline Multiple Choice SPS Test & $1 / 38$ &, 701 &, 408 \\
Open-Ended SPS Test & $1 / 38$ &, 360 &, 552 \\
Performance-Based Test & $1 / 38$ &, 696 &, 410 \\
\hline
\end{tabular}

When Table 2 is examined, Levene F test values are higher than the limit value of .05. This value shows that there is no significant difference between the groups in terms of the distribution of error variances of the dependent variables in determining the homogeneity of error variances. In addition, this value shows that variances are homogeneous. In line with the analyzes, it was decided that the necessary assumptions were met in order to use MANOVA and analyzes were carried out.

\section{Findings Regarding SPS Levels of Students with Field Dependent and Field Independent Cognitive Styles}

The results obtained from the one-way MANOVA analysis of the scores obtained from the multiple choice, open-ended and performance-based tests of the students with field dependent and field independent cognitive styles are given in Table 3 . 
Table 3. MANOVA results of the multiple choice, open-ended and performance-based tests scores according to

\begin{tabular}{llllll}
\multicolumn{7}{l}{ cognitive styles } \\
\hline Effect & Wilks' $\lambda$ & $F$ & Hypothesis sd & Error $s d$ & $p$ \\
\hline Cognitive Style & 0.617 & 7.452 & 3 & 36 & 0.001 \\
\hline
\end{tabular}

MANOVA results reveal that students with field dependent and field independent cognitive style showed a significant difference in terms of scientific process skills scores measured by different tests [Wilks Lambda $(\lambda)$ $=0.617, \mathrm{~F}(3,36)=7.452, \mathrm{p}<.05]$. This finding showed that the scores obtained from the linear component consisting of multiple-choice test, open-ended test and performance-based test scores differ depending on the cognitive style differences.

Within the scope of the study, findings the analysis of variance regarding whether the scientific process skills measured by the multiple choice, open-ended and performance-based tests differ according to student's cognitive styles are presented in Table 4.

Table 4.Variance analysis of multiple choice, open ended and performance based sps scores according to

\begin{tabular}{|c|c|c|c|c|c|c|c|}
\hline Test & Cognitive Style & $N$ & $\bar{x}$ & $S$ & $S D$ & $F$ & $p$ \\
\hline \multirow[t]{2}{*}{ Multiple Choice SPS } & Field Dependent & 20 & 8,4 & 1,78 & $1-38$ & \multirow{2}{*}{15,69} & \multirow{2}{*}{, 000} \\
\hline & Field Independent & 20 & 10,85 & 2,1 & $1-38$ & & \\
\hline \multirow[t]{2}{*}{ Open-Ended SPS } & Field Dependent & 20 & 31,1 & 9,5 & $1-38$ & \multirow{2}{*}{,394 } & \multirow{2}{*}{, 534} \\
\hline & Field Independent & 20 & 33,11 & 10,5 & $1-38$ & & \\
\hline \multirow{2}{*}{$\begin{array}{c}\text { Performance Based } \\
\text { SPS }\end{array}$} & Field Dependent & 20 & 33,35 & 9,2 & $1-38$ & \multirow{2}{*}{, 146} & \multirow{2}{*}{,705 } \\
\hline & Field Independent & 20 & 32,15 & 10,6 & $1-38$ & & \\
\hline
\end{tabular}

Considering the values in Table 4, in terms of Multiple Choice SPS test mean scores $[F(1,38)=15.69$, $p<.05]$, the scores of the students with field independent cognitive style were statistically higher than the students with field independent cognitive style. When the open-ended SPS test mean scores $[\mathrm{F}(1,38)=.554 \mathrm{p}>.05]$ and Performance Based SPS test mean scores $[\mathrm{F}(1,38)=.705 \mathrm{p}>.05]$ are examined, there is no significant difference between test scores of the students with field independent and field dependent cognitive styles.

\section{Results and Discussion}

Scientific process skills of students who have different cognitive styles within the scope of the research were measured in three different test formats: multiple choice, open-ended and performance based. Findings obtained; showed that students with field independent cognitive style were more successful in multiple choice SPS test. However, it was concluded that there was no significant difference between the achievements of students in the field-dependent and field-independent cognitive style in both open-ended and performance-based tests.

When the relevant literature is examined, no research has been found regarding the measurement and interpretation of scientific process skills according to cognitive styles, which is an individual difference. However, research examining the relationship between individual characteristics such as creativity (Aktamis and Ergin, 2007), critical thinking (Akar, 2007; Koray, Köksal and Özdemir, 2007; Rudd, Baker and Hoover, 2000) and emotional intelligence (Ergin and Özgürol, 2011) and scientific process skills attracts attention. In addition, studies investigating the relationships between learning styles and SPS (Arı and Bayram, 2011; Duran, Işık and Mihladız, 2011) suggest that some learning styles are more advantageous in terms of SPS.

The results of this research showed that students with different cognitive styles have different success in scientific process skills. This may be due to the difference of students' cognitive style tendencies, the test format used to measure scientific process skills or the structure of the measured scientific process skills. To start with students' cognitive style features; Field Independent students can be more successful in the tests with multiple choice questions test format due to the features of not being effected by the illusion of the fields, analyzing the fields (Liu and Reed, 1994), distinguishing the differences easily (Simsek, 2004). However, Witkin, Moore, Goodenough and Cox (1977) stated that students with field independent cognitive style are more easily able to recognize unstructured problems, wrong structures in activities, and unclear hints of problems. As a matter of fact, this finding has been revealed by various studies (Karacam, 2005; Karacam and Ates, 2010). The absence of a significant difference in terms of the scores of fields independent and field dependent students in the openended and performance-based scientific process skills test shows that the advantage/disadvantage arising from 
the measurement tool in measuring scientific process skills may be eliminated. In the research, questions about determining variables and establishing hypotheses in open-ended questions require higher level qualifications (Temiz, 2007). In addition, in performance-based questions, the student is expected to design an experimental setup, test the hypothesis, and interpret the collected data. This type of test, on the other hand, provides the student with the opportunity to fully demonstrate his/her scientific process skill beyond the ability to solve multiple choice questions. It is possible to explain this result with Saracho's (1997) statement that field dependent and field independent students have the same level of cognitive capacity, however, their ability to use information and the process of using materials may differ. In addition, Güven (2007) stated that not only can each style have positive features, but also negative features, and in some cases, it is important to see the detail, in some cases it may be an important the whole. In this context, diversification of measurement tools (Monica, 2005) appears to be an important issue in the measurement of scientific process skills since the types of questions prepared in various types can effect students with different cognitive styles in different ways. Research states that cognitive style differences are a factor that teachers should take into account in shaping learning environments and developing flexibility, improving the quality of education of all children and improving educational opportunities (Saracho, 2017). In addition, it should be noted that an effective teaching process is shaped and completed by an effective evaluation process. The use of measuring instruments in different formats both during the teaching process and at the end will ensure that the disadvantages caused by cognitive styles are eliminated. In fact, research showed that cognitive styles can effect students' preferences for learning process (Saracho, 2017). For this reason, it is necessary to care about the individual differences of the students and not to impose only a uniform assessment activity on the student. Indeed, Hamblin (1981, p.21) described this situation as the pedagogically equivalent of imposing a false self on someone and expresses it as a destructive act in the long run. In line with the findings obtained from the research, it can be said that openended and performance-based test results provide important data to the teacher about the skills that the student needs to be developed-supported and their preferences regarding teaching and assessment activities.

\section{Recommendations}

The findings of this study show that when scientific process skills are measured with open-ended and performance-based tests, there is no significant difference between students with different cognitive styles, but when scientific process skills are measured with multiple choice test, a result is in favor of field independent students. This result shows that there is a need to discuss how scientific process skills should be measured. For this reason, it is thought that using open-ended or performance-based tests by moving away from traditional methods in measuring scientific process skills will produce more valid results. In this context, researchers are recommended to develop valid-reliable SPS measurement tools that include question types in different formats suitable for the Curriculum.

The scarcity of research in the field clearly reveals the necessity to investigate the relationship between scientific process skills and cognitive styles. In addition, the findings of this study reveal the possibility that the results obtained by measuring scientific process skills may result from differences in students' cognitive styles. If there are differences between SPS achievements measured using different measurement techniques, the findings of previous studies investigating SPS success should be reviewed. In this context, researchers are advised to conduct research that deals with the relationship between scientific process skills and cognitive styles, and that takes care of students' individual differences in determining and developing scientific process skills.

\section{References}

Akar, Ü. (2007). Sınıf ögretmeni adaylarının bilimsel süreç becerileri ve eleştirel düşünme becerileri arasındaki ilişki. (Master Thesis). Afyon Kocatepe Üniversitesi.

Aktamıs, H., \& Pekmez, E. S. (2011). Fen ve teknoloji dersine yönelik bilimsel süreç becerileri ölçeği geliştirme çalışması. Buca Eğitim Fakültesi Dergisi, 30, 192-205.

Aktamış, H., \& Ergin, Ö. (2007). Bilimsel süreç becerileri ile bilimsel yaratıcılık arasındaki ilişkinin belirlenmesi. Hacettepe Üniversitesi Ĕ̈itim Fakültesi Dergisi, 33(33), 11-23.

Alamolhodaei, H. (1996). A study in higher education calculus and students' learning styles. (Doctoral dissertation). University of Glasgow.

Arı, E., \& Bayram, H. (2011). Yapılandırmacı yaklaşım ve öğrenme stillerinin laboratuvar uygulamalarında başarı ve bilimsel süreç becerileri üzerine etkisi. Ilköğretim Online, 10(1), 311-324 
Ates, S. (2001). The effects of computer applications online-graphing skills of tenth grade students having different cognitive developmental levels (pp. 1-198). University of Kentucky.

Ates, S. (2005). Öğretmen Adaylarının Değişkenleri Belirleme ve Kontrol Etme Yeteneklerinin Geliştirilmesi. Gazi Üniversitesi Gazi Eğitim Fakültesi Dergisi, 25(1), 21-39.

Aydoğdu, B., Tatar, N., Yıldız, E. ve Buldur, S. (2012) İlköğretim öğrencilerine yönelik bilimsel süreç becerileri ölçeğinin geliştirilmesi. Journal of Theoretical Educational Science, 5(3), 292-311.

Balc1, A. (2005). Sosyal bilimlerde araştırma: yöntem teknik ve ilkeler. Ankara: TDFO.

Bekiroglu Ogan,F. (2008). Performansa dayalı ölçümler: teori ve uygulama. Journal of Turkısh Scıence Education, 5 (1), 113-131.

Bozkurt, O. ve Olgun, Ö. S. (2005). Fen ve teknoloji eğitiminde bilimsel süreç becerileri. M. Aydoğdu ve T. Kesercioğlu (Ed.), Illkögretimde fen ve teknoloji ögretimi (s. 55-70). Ankara: Anı Yayıncılık.

Burns, J. C., Okey, J. R., \& Wise, K. C. (1985). Development of an integrated process skill test: TIPS II. Journal of Research in Science Teaching, 22(2), 169-177.

Büyüköztürk, Ş. (2007). Sosyal bilimler için veri analizi el kitabı. Ankara: Pegem Akademi.

Century, D. N. (2002). Alternative and traditional assessments: their comparative impact on students' attitudes and science learning outcomes: an exploratory study. (Doctoral dissertation). University of Temple, USA.

Cohen, L., Manion, L., \& Morrison, K. (2002). Research methods in education. 5th Edition, London: Routledge.

Demirçalı, S. (2016). Modellemeye dayalı fen öğretiminin öğrencilerin akademik başarılarına, bilimsel süreç becerilerine ve zihinsel model gelişimlerine etkisi: 7. sınıf güneş sistemi ve ötesi-uzay bilmecesi ünitesi örneği. (Master thesis). Gazi Üniversitesi Ĕ̆itim Bilimleri Enstitüsü, Ankara.

Dillashaw, G.F., \& Okey, J. R. (1980). Test of the integrated science process skills for secondary science students. Science Education, 64(5), 601-608.

Duran, M., Işık, H., Mıhladız, G., \& Özdemir, O. (2011). The relationship between the preservice science teachers' scientific process skills and learning styles. Western Anatolia Journal of Educational Science, Special Issue: Selected papers presented at WCNTSE, 467-474.

Ergin, D. Y., Özgürol, M.B. (2011). Bilimsel Tutum ve Duygusal Zekâ Arasındaki İlişki. 2nd.International Conference on New Trends in Education and Their Implications, 27-29 April 2011, Antalya-Turkey.

Ergin, Ö., Şahin-Pekmez, E., \& Öngel-Erdal, S. (2005). Kuramdan uygulamaya deney yoluyla fen öğretimi. İzmir: Dinazor.

Feyzioğlu, B.,Demirdağ, B., Akyıldız, M. ve Altun, E. (2012). Ortaöğretim öğrencilerine yönelik bilimsel süreç becerileri testi geliştirilmesi: Geçerlik ve güvenirlik çalışması. Kuram ve Uygulamada Eğitim Bilimleri, 12(3), 1887.

Güven, B. (2007). Öğretimde bireysel farklılıklara bakış: bilişsel stiller. Yeditepe Üniversitesi Eğitim Fakültesi Dergisi (EDU7), 2(2), 2-3.

Harlen, W. (1999). Purposes and procedures for assessing science process skills. Assessment in Education: principles, policy \& practice, 6(1), 129-144.

Hamblin, D. H. (1981) Teaching Study Skills. Oxford: Basil Blackwell.

Jonassen, D., \& Grabowski, B. (1993). Individual differences and instruction. New York: Allen \& Bacon.

Karaçam, S. (2005). Farklı bilişsel stillerdeki lise ögrencilerinin hareket ve hareket yasaları konularındaki kavramsal anlama düzeyleri ile ölçme teknikleri arasındaki ilişki (Master Thesis). Abant İzzet Baysal Üniversitesi Sosyal Bilimler Enstitüsü, Bolu.

Karaçam, S., \& Ateş, S. (2010). Ölçme tekniğinin farklı bilişsel stillerdeki öğrencilerin hareket konusundaki kavramsal bilgi düzeylerine etkisi. Abant İzet Baysal Üniversitesi Eğitim Fakültesi Dergisi, 10(1), 2130.

Koray, Ö., Köksal, M. S., Özdemir, M., \& Presley, A. İ. (2007). Yaratıcı ve eleştirel düşünme temelli fen laboratuvarı uygulamalarının akademik başarı ve bilimsel süreç becerileri üzerine etkisi. İlkögretim Online, 6(3), 377-389.

Liu, M., \& Reed, W. M. (1994). The relationship between the learning strategies and learning styles in a hypermedia environment. Computers in Human Behavior, 10(4), 419-434.

Lowery, L. F. (Ed.). (1997). NSTA Pathways to the science standards (Vol. 1). Arlington: NSTA Press.

Meador, K. S. (2003). Thinking creatively about science suggestions for primary teachers. Gifted Child Today, 26(1), 25-29.

Mefoh, P. C., Nwoke, M. B., Chukwuorji, J. C., \& Chijioke, A. O. (2017). Effect of cognitive style and gender on adolescents' problem-solving ability. Thinking Skills and Creativity, 25, 47-52.

Messick, S. (1982). Cognitive styles in educational practice. ETS Research Report Series, 1982(1), 1-34.

Molitor, L. L., \& George, K. D. (1976). Development of a Test of Science Process Skills. Journal of Research in Science Teaching, 13(5), 405-412.

Monica, K. M. M. (2005). Development and validation of a test of integrated science process skills for the further education and training learners. (Master's Thesis), University of Pretoria. South Africa. 
OECD (2019). PISA 2018 Results (Volume I): What Students Know and Can Do. PISA, OECD Publishing, Paris, https://doi.org/10.1787/5f07c754-en.

Oltman, P.K, Raskin, E. \& Witkin, H.A. (1971). Group embedded figures test booklet. All rights reserved 2003. Published by Mind Garden, Inc.

Ostlund, K. L. (1992). Science process skills: assessing hands-on student performance. Addison-Wesley, Innovative Division, 20665 4th St., Saratoga, CA 95070.

Ozarslan, M., \& Bilgin, İ. (2016). The effects of the students' cognitive styles of field dependent/independent. Mustafa Kemal Üniversitesi Sosyal Bilimler Enstitüsü Dergisi, 13(33), 94-110.

Özkan, B. (2015). 60-72 aylık çocuklar için bilimsel süreç becerileri ölçeğinin geliştirilmesi ve beyin temelli ögrenmeye dayanan fen programının bilimsel süreç becerilerine etkisi. (Doctoral dissertation). Marmara University, İstanbul.

Padilla, M.J. (1990). The science process skills. Research matters - to the science teacher. National Association for Research in Science Teaching, 9004.

Parkinson, J. (1998). The effective teaching of secondary school. UK:Longman Group UK Limited.

Rasinski, T. V. (1984). Field dependent/independent cognitive style research revisited: do field dependent readers read differently than field independent readers? Reading psychology, 5(3), 303-322.

Rezba, R., Sprague, C., McDonnough, J., \& Matkins, J. (2007). Learning and Assessing Science Process Skills. Dubuque, Iowa. America: Kendall Hunt Publishing Company, 303-313.

Riding, R., \& Rayner, S. (2012). Cognitive styles and learning strategies: Understanding style differences in learning and behavior. London: David Fulton Publishers.

Rudd, R., Baker, M., \& Hoover, T. (2000). Undergraduate agriculture student learning styles and critical thinking abilities: Is there a relationship? Journal of agricultural education, 41(3), 2-12.

Saracho, O. N. (1997). Teachers' and students' cognitive style in early childhood education. Westport: Bergin \& Garvey.

Saracho, O. N. (2017). Cognitive style and the evaluation of young children's educational programs. In Cognitive Style in Early Education (pp. 43-58). NY: Routledge.

Sari, M., Altiparmak, M., \& Ateş, S. (2013). Test yapısının farklı bilişsel stillerdeki öğrencilerin mekanik başarisina etkisi. Hacettepe Üniversitesi Ĕ̈itim Fakültesi Dergisi, 28(1), 334-344.

Solano-Flores, G. (2000). Teaching and assessing science process skills in physics: the "bubbles" task. Science Activities, 37(1), 31-37.

Spector, P. E. (1992). Summated Rating Scale Construction: An Introduction. Sage University Papers Series. Quantitative Applications in the Social Sciences; No. 07-082. Iowa City: Sage Publications.

Sternberg, R. J., \& Grigorenko, E. L. (1997). Are cognitive styles still in style? American psychologist, 52(7), 700.

Şimşek, A. (2004). Öğrenme biçimi (Learning style). Y. Kuzgun and D. Deryakulu (Ed.), in Eğitimde Bireysel Farkllliklar (Individual Differences in Education) (pp. 95-136). Nobel: Ankara.

Tan, M., \& Temiz, B. (2003). The importance and role of the science process skills in science teaching. Pamukkale University Journal of Education, 1(13), 89-101.

Temiz, B.K. (2007). Fizik öğretiminde öğrencilerin bilimsel süreç becerilerinin ölçülmesi. (Doctoral dissertation). Gazi Üniversitesi, Eğitim Bilimleri Enstitüsü, Ankara.

Wiggins, G. (1996). Practicing what we preach in designing authentic. Educational Leadership, 54(4), 18-25.

Witkin, H. A., Moore, C. A., Goodenough, D. R., \& Cox, P. W. (1977). Field-dependent and field-independent cognitive styles and their educational implications. Review of educational research, 47(1), 1-64.

Witkin, H. A. (1977). Cognitive styles in personal and cultural adaptation. Worcester, MA: Clark University Press.

Witkin, H. A., \& Goodenough, D. (1981). Cognitive styles essence and origins: Field dependence and field independence psychological issues. New York: International University Press.

Witkin, H. A., Oltman, P. K., Raskin, E., \& Karp, S. A. (1971). Manual for embedded figures test, children's embedded figures test, and group embedded figures test. Palo Alto, Calif.: Consulting Psychologists Press, Inc.

\begin{tabular}{ll}
\hline \multicolumn{2}{c}{ Author Information } \\
\hline Sema Aydın Ceran & Salih Ates \\
Selcuk University, Konya, Turkey & Gazi University, Science Education Department, Ankara \\
Contact e-mail: sema.aydin.ceran@ gmail.com & Turkey \\
ORCID iD: 0000-0001-6847-2766 & ORCID iD:0000-0003-0425-0982 \\
\hline
\end{tabular}

